\title{
Vivência do familiar da pessoa em sofrimento psíquico
}

Experiences of family members to a person with mental suffering

Nesta investigação, buscou-se apreender como as famílias dos pacientes vivenciam a experiência do sofrimento psíquico e como percebem os serviços de saúde mental. Para alcançar esse objetivo, fez-se necessário entender a trajetória das famílias desde a constituição da psiquiatria enquanto ciência médica, quando os familiares eram excluídos do cuidado ao doente mental, até nossos dias, quando a família passa a compartilhar com a equipe e pacientes o projeto terapêutico. Também realizou-se um estudo de caso para conhecer o entendimento da família frente ao adoecimento e como seus membros convivem com o paciente. A análise desenvolvida a partir das entrevistas revelou que os familiares concebem o sofrimento psíquico baseado no paradigma da psiquiatria, como uma doença incurável e de evolução crônica. Diante disso, evitam causar atritos para impedir futuras crises, buscando um clima de harmonia. Utilizam a crença religiosa para trazer conforto frente ao sofrimento a ser enfrentado. Recorrem aos serviços de saúde mental quando não conseguem controlar os comportamentos inadequados do paciente $e$ solicitam a internação integral quando o mesmo torna-se agressivo. O hospital-dia é compreendido como um local onde o doente permanece por um período do dia para ocupar seu tempo e, dentre as atividades desenvolvidas, o grupo de familiares representa um espaço de troca entre a equipe, os pacientes e as famílias, objetivando melhorar seu relacionamento. No atendimento ao núcleo familiar em sua residência, observou-se que o profissional tem que aprender a trabalhar com as circunstâncias advindas de um outro espaço de atuação, no qual a história da família está impregnada em cada canto da casa, bem como sua forma característica de lidar com a pessoa em sofrimento psíquico.

Vânia Moreno Tese de Doutorado, 2000 Programa de Doutorado Interunidades das Escolas de Enfermagem Ribeirão Preto e São Paulo, Universidade de São Paulo

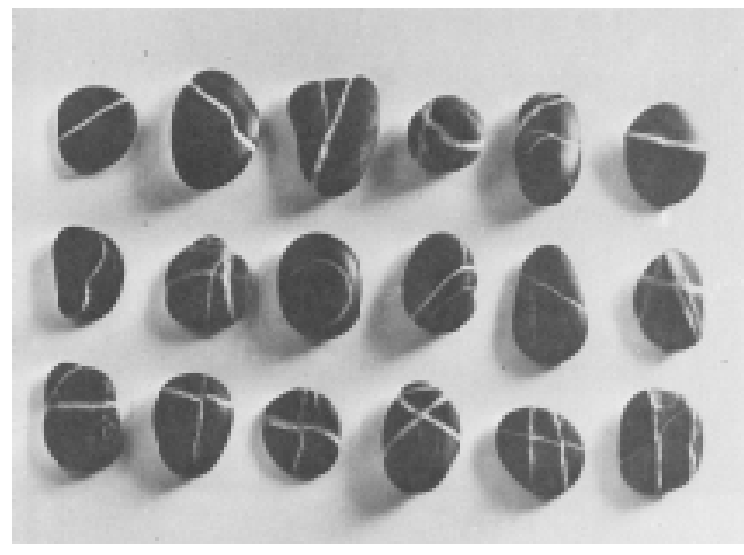

STAGNARO, Itália, XVI Bienal de São Paulo, 1981
PALAVRAS-CHAVE: atendimento a família; sofrimento psíquico; serviço de saúde mental.

KEYWORDS: family oriented services; mental suffering; mental health services. PALABRAS CLAVE: atendimiento a la família; sufrimiento psíquico; servicios de salud mental.

Recebido para publicação em: 22/02/01. Aprovado para publicação em: 04/06/01. 